\title{
К.И. САТПАЕВ И А.Х. МАРГУЛАН - ИСТОРИЯ СОТРУДНИЧЕСТВА
}

\author{
(C) 2019 г. Д.А. Маргулан
}

Посвящается 120-летию К.И. Сатпаева и 115-летию А.Х. Маргулана

В этом году исполнилось 120 лет К.И. Сатпаеву и 115 лет А.Х. Маргулану. К.И. Сатпаев и А.Х. Маргулан родились в Баянауле Павлодарской области. Учились в 1920-е годы в Семипалатинском педагогическом техникуме. В последующем К.И. Сатпаев продолжил обучение в Сибирском технологическом институте (г. Томск), a А.X. Маргулан - в Ленинградском государственном университете на факультете востоковедения. После окончания Томского института Каныш Имантаевич был направлен на работу в Карсакпай, где проработал с 1928 г. по 1941 г. - до образования в г. Алма-Ате Казахского филиала Академии наук СССР. А.Х. Маргулан в 1938 г. решением Президиума АН СССР был направлен из Института истории материальной культуры (Ленинград) в сектор истории КазФАН СССР, затем в 1946 г. - сектор археологии. С этого момента начинается история Центрально-Казахстанской археологической экспедиции, бессменным руководителем которой А.Х. Маргулан оставался многие годы.

Ключевые слова: археология, К.И. Сатпаев, А.Х. Маргулан, КазФАН СССР, сотрудничество

\section{Вместо Предисловия}

Мне часто приходилось слышать разговоры отца с дядей моей мамы - Канышем Имантаевичем Сатпаевым. История сотрудничества двух великих казахских ученых создавалась и творилась не только в здании Академии наук, но и в нашем доме и в доме К.И. Сатпаева, куда мы часто наведывались.

В процессе редактирования трудов отца, ознакомления с оставшимися документами и воспоминаниями, у меня возникло понимание событий, изложенное ниже. Думаю, что я недалека от истины.

\section{Начало сотрудничества}

На протяжении 13 лет К.И. Сатпаев работал в Карсакпае. Он прекрасно знал все памятники, расположенные в данной местности. Каныш Имантаевич глубоко интересовался историей своего народа, его фольклором. Об этом говорит факт издания в 1928 году в г. Москве эпического сказания «Ер Едиге» на казахском языке с предисловием К.И. Сатпаева.

В Карсакпае К.И. Сатпаев собрал ценные сведения по древним выработкам Жезказгана, составил сводку археологических памятников этого района, а также наскальных гравюр в местности Байконур.

Предложение А.Х. Маргулану работать в сфере археологии было не случайным. Солидное образование, его необычайный интерес к казахской истории, пытливый ум и трудолюбие, огромный опыт работы с архивными материалами - все эти качества отца обусловили предложение К.И. Сатпаева возглавить археологию в Казахстане. 
Каныш Имантаевич поделился своими знаниями с А.Х. Маргуланом и они, по-видимому, выработали стратегию исследований памятников. Как геолога, К.И. Сатпаева особенно интересовала история горных выработок. Изучение этого вопроса находится на стыке нескольких наук: горного дела, геологии, металлургии, археологии и др., поэтому А.X. Маргулану постоянно было необходимо консультироваться со специалистами, в первую очередь с К.И. Сатпаевым, обращаться к его трудам.

ЦКАЭ под руководством А.Х. Маргулана начала работать в Жезказган-Улытауском регионе. Одновременно с памятниками археологии обследовались древние выработки, сакральные объекты (мавзолей Джучи, Алаша-хана), петроглифы в местности Байконур и др.

A.X. Маргуланом изучались литературные источники и архивные материалы по древнему горному делу и металлургии, труды геологов и, в частности, труды К.И. Сатпаева. Благодаря этим источникам, результатам полевых работ, советам К.И. Сатпаева появилась монография А.Х. Маргулана «Сарыарка. Горное дело и металлургия в эпоху бронзы» [Маргулан А.Х., 2008а].

О книге, посвященной древним выработкам, появившейся в результате сотрудничества К.И. Сатпаева и А.Х. Маргулана

О древних выработках в казахских степях стало известно со времени первой российской академической экспедиции, работавшей в Казахстане в середине XVIII в. Развитие горного дела и металлургии на территории Сарыарки с древнейших времен было обусловлено полиметаллическими месторождениями, громадными массами, сосредоточенными на террито- рии Центрального Казахстана. Здесь сохранилось большое число древних рудников, отвалов, карьеров, оплывших ям, забоев, шахт, штолен. Среди них выделяются грандиозные рудные объекты - комплексы Жезказган, Каражал (Шетский район), группы рудников Северного Прибалхашья, Каркаралинской, Баянаульской и Карагандинской степей, Северной Бетпакдалы, групп Имантау, Степняк, Бесоба.

Результаты топографических исследований, проведенных в советское время, свидетельствуют о том, как обширны и многочисленны древние рудные выработки Сарыарки. Они встречаются повсюду на огромном степном пространстве от Улытау и Жезказгана до Калбинского хребта, Алтая и Тарбагатая. Следы горных работ поражают тщательной продуманностью и целесообразностью их ведения. В результате усилий горных инженеров Жезказгана и лично К.И. Сатпаева из древних выработок Центрального Казахстана наиболее обстоятельно были изучены рудные выработки Жезгазгана [Сатпаев, 1967 , c. $68-69,79 ; 1968$, c. $53-87,90-$ 100; 1970, c. 45].

В Сарыарке известно два типа древних выработок: открытые и подземные. Открытый способ добычи и соответственно малые выработки небольшой глубины характерны для ранних этапов эпохи бронзы. Они представляют собой неглубокие ямы овальной формы, располагающиеся по простиранию рудного тела. В эпоху Бегазы-Дандыбая в горном деле наблюдается большой прогресс, многовековой опыт подводит древних горняков к освоению глубоко лежащих пластов руды, в результате чего появляется шахтный тип выработок. 
Жезказган, Коунрад и Саяк относятся к одним из крупнейших месторождений меди в мире. Мощность окисленной медной руды в Жезказгане велика, ее нижний горизонт находится на глубине 50-60 м. Сокровища недр Жезказгана были открыты еще древними жителями Сарыарки. Их многовековые усилия привели к образованию крупнейшего центра древнего металлургического производства. Об этом свидетельствуют обширные и многочисленные карьеры, грандиозные отвалы и разносы, остатки поселений древних рудокопов Златоуст, Милыкудук, Айнаколь, Соркудук, где в культурных слоях обнаружены предметы материального производства: орудия труда, предметы бытового обихода, слитки меди, керамика, обломки тиглей, шлаки. В начале 1930-х годов древние выработки Жезказгана находились еще в нетронутом состоянии.

Древний массив Жезказгана стал объектом исследований после Великой Отечественной войны. Внимание к изучению древних выработок региона проявил президент только что созданной Академии наук КазССР К.И. Сатпаев [1970, с. 453].

Древним обитателям Сарыарки раскрылась суть обработки руды, заключающаяся в ее дроблении, измельчении и обогащении. Собственно, этот же процесс лежит в основе современного металлургического производства.

Древние горняки добытую руду сортировали и обогащали в несколько приемов. Предварительное очищение ее от пустых пород производилось в самом забое. Первоначальный этап обработки руды в древности проводился в стороне от выработок, в черте поселений рудокопов, вблизи водных источников - озер, рек, колодцев, искусственных водоемов. Русла рек преграждались плотинами из глыб гранита, поставленных на ребро. Серия плотин была обнаружена и обследована в Каркаралинской и Баянаульской степях, густая сеть плотин обследована возле древних выработок Жезказгана. Следы обогащения руды в виде многочисленных ям - остатков древних водоемов, отвалов, груд измельченных и промытых руд, «сплесков», «хвостов» присутствуют вблизи ряда древних выработок Центрального Казахстана: Саяке, Коунраде, Алтынсу, Шакпактасе, Жосалы, Майкаине, Бестобе, Степняке, Имантау, Жезказгане. Места обогащения руды с отвалами измельченной руды открыты во многих местах Центрального Казахстана К.И. Сатпаевым и др. На территории Сарыарки в эпоху бронзы места дробления и обогащения руды, как правило, находились рядом с древними плавильными центрами, что свидетельствует о комплексном характере производственных процессов (обогащение руды и плавка в одном месте). Следы древнего металлургического производства сконцентрированы в плавильных центрах Жезказгана (Милыкудук, Соркудук, Айнаколь), в обрыве реки Жезды [Сатпаев, 1970, c. 453].

В древности местами сбора воды для мокрого обогащения измельченной руды были «сплески» - группы ям, окруженные отвалами дробленой руды. Ямы представляли собой водосборные бассейны диаметром 3 м, глубиной 2-3 м. При отсутствии проточной воды бассейн снабжался водой из колодца, выложенного камнями и расположенного на дне большой ямы. В полупустынных районах использование колодцев для устройства водоемов и запруд в 
металлургическом

производстве имело огромное значение. Многолетние археологические раскопки позволили обнаружить и обследовать в древних плавильных центрах Жезказгана большую серию плавильных печей, относящихся к разному времени. По типу они различны. Наиболее раннюю серию плавильных печей составляют костровые ямы и каменные очаги, сложенные из валунов песчаника или кварцита в форме круга диаметром 1,5-2 м, глубиной до 60-80 см. На дне таких очагов или костровых ям прослеживаются остатки древесного угля, шлаки, обломки самородной меди. В подобных случаях мы имеем дело с более ранними формами плавки.

Другая серия древних плавильных печей, обнаруженных в Жезказгане и других районах Центрального Казахстана, представляет собой небольшие горны в виде круглых ям, обложенных тонкими сланцевыми плитами или обмазанных глиной с наклоном пода к устью, что специально сделано для циркуляции воздуха.

Распространенный тип плавильных печей, встречающихся в Жезказгане и других районах Казахстана, представляет собой сыродутные печи. Описание одной из них: печь прямоугольной формы с устьем полукруглого очертания. Основание погружено в грунт до 1 м. Наружные стены выведены кладкой из сланцевых плит с коробовым сводом высотой 0,6 м. Над сводом возвышается сопло в виде усеченного конуса. Размеры печи: длина 2 м, ширина 1 м, высота 1,2 м. Две другие печи, остатки которых сохранились на отдельных участках культурного пласта Милыкудука, гораздо более крупных размеров, чем предыдущая. Одна из них шахтного типа: печь прямоугольной формы, разделена поперечной стенкой на две камеры, в одной из которых производилась плавка исходных продуктов, в другой - вторичных. Вторая печь самая крупная из всех плавильных печей Жезказганского металлургического центра. Величина печи наводит на предположение, что она была предназначена для кучевого обжига руды.

Материалы из плавильных печей Жезказгана свидетельствуют о том, что в качестве топлива при плавке руды использовался саксаул, степной кустарник, кизяк, а также кости животных. Так, в зольном слое плавильных печей Жезказгана прослежены остатки таволги, саксаула, кизяка и большое скопление обгорелых костей. По подсчетам геологов, для получения 15 кг черной меди требовалась тонна степного кустарника.

О загрузке плавильных печей Жезказгана свидетельствуют огромные скопления шлаков. Химический анализ показал, что шлаки происходят из различных плавильных центров разного качества: шлаки пористые и шлаки плотные (черные и темно-коричневые).

Наиболее крупным медеплавильным центром в бассейне р. Сарысу после Жезказгана было поселение древних металлургов Атасу, находившееся в 98 км к востоку от рудника Каражал (Жанааркинский р-н). Площадь поселения, занимавшего около 5 га, была покрыта обломками керамики, костями животных, рудодробильными орудиями, шлаками и грудами медной руды и насыщена следами древнего металлургического производства: местами обогащения медной руды в виде бугров, рвов, остатков древних каналов, водосборных ям, плотин. При раскопках по- 
селения в 1955 г. в обрыве протока были обнаружены следы древней мастерской в виде продолговатой ямы длиной 10 м, шириной 4,5 м с зольным слоем толщиной до 0,6 м. На дне мастерской были расположены подовые части трех плавильных горнов круглой формы диаметром 2-2,8 м с сохранившейся глубиной 25-30 см. На дне и вокруг печей обнаружены большие скопления шлаков, золы, угольков, груды измельченной медной руды, медные шарики, обломки бронзового шила и др. Значительное скопление каменных орудий, шлаков, слитков меди (один слиток весом до 5 кг), каменных льячек, обломков тиглей, форм для литья и других орудий обработки металла обнаружено в культурном слое жилища № 4 поселения Атасу вокруг большого домашнего очага, служившего не только для обогрева, но и для плавки медной руды.

Химический анализ шлаков из поселения Атасу, проведенный T.А. Сатпаевой, свидетельствует о том, что для плавки использовались наиболее богатые медью руды (до 20-47\%) верхнего горизонта, легко доступные для добычи.

Одним из крупных плавильных центров в древности было Северное Прибалхашье. Об этом свидетельствуют древние ямы с отвалами, «сплески», скопления шлаков со следами плавки медной и свинцовой руд, обнаруженными на южном склоне горы Карашокы, в Восточном Коунраде, горах Кенели, Тесиктас, Жаман-Кызыларай, Жангызтау. Мощные следы добычи и плавки руды обнаружены в Саяке I, III-V.

Значительные следы древнего металлургического производства находятся в Каркаралинской степи (Шетский район). Здесь, недалеко от рудных выработок Кызылэспе, Акшагыл, Акжал, Каскаайгыр, Кызыладыр, Жалпак - известных полиметаллических месторождений находился один из основных плавильных центров Западно-Каркаралинской степи. Группа медеплавильных печей обнаружена на территории совхоза «Бесоба» (Каркаралинский р-н). Остатки древних плавильных печей обнаружены на поселении эпохи бронзы Бугулы I (Шетский р-н). В этом же регионе при раскопках поселения Шортанды-Булак были обнаружены следы металлургического производства. Группа древних плавильных печей обнаружена в ущельях главного Каркаралинского хребта. Здесь в эпоху бронзы находился крупнейший металлургический центр всей Каркаралинской степи, включая центры Актогайского, Шетского и Егиндыбулакского районов.

Остатки древних плавильных центров обнаружены горным инженером И.А. Могилевским в обрыве p. Каркаралинки на площади поселения Каркаралы, в северо-западных окрестностях г. Каркаралинска. В обрыве р. Каркаралинки местным краеведом В.Е. Ясенецкой также выявлены остатки ряда плавильных печей. Крупными плавильными центрами эпохи бронзы были поселения Каркаралинск II, III (Суукбулак), IV, находившиеся в окрестностях современного г. Каркаралинска.

Основной сырьевой базой для каркаралинских металлургических поселений в древности были рудники с радиусом расположения 2-30 км и более. Месторождения в районе Главного Каркаралинского хребта имели полиметаллический характер и содержали медь, свинец, цинк, сурьму, серебро, золото, реже олово. Олово для сплава бронзы добывали 
в рудниках, расположенных в горах Шайтанды, между Каркаралинскими и Баянаульскими горами.

В Баянаульском горнометаллургическом центре обнаружены следы производства в виде скопления шлаков около выработок Жосалы, Шакпактас, Ескижурт, Казанауз и Сарыадыр. Все, за исключением Жосалы, находятся у северного подножия Баянаульского хребта, вблизи Баянаула и оз. Жасыбай.

Огромные скопления шлаков установлены на местах плавки руды в горах Куу, в урочище Каиндышат, вблизи древних выработок Ушкатын, Кентобе, Акшокы, на северных склонах горы Бакты, в поселениях эпохи бронзы Шортанды-Булак, Каркаралы III, Тагибай-Булак, в горах Темирши. Мест нахождения шлаков установлено значительно больше, чем плавильных печей. Образцы шлаков, как продукта плавки руды в древности, были собраны во многих местах Центрального Казахстана. Их коллекции хранятся в музеях Жезказгана, Караганды, Балхаша, Алматы.

Слитки металла - конечного продукта металлургического производства, из которого создавались предметы труда и обихода и который был предметом экспорта, в значительном количестве обнаружены в ряде плавильных центров. Так, их много найдено на площади поселения Каркаралы I, три слитка черной меди обнаружены жителем в огороде вблизи р. Каркаралинки. Один из слитков в форме эллипса имел размеры $25 \times 22$ см, вес 7,2 кг. В обрыве p. Каркаралинки краеведом В.Е. Ясенецкой обнаружен слиток бронзы весом 400 г. Слитки бронзы обнаружены на поселениях Атасу, ШортандыБулак, Каркаралы III, на поселениях и в могильниках Жезказгана, на вы- работках Саяка. В Саяке III в древней штольне на глубине 12 м обнаружены два массивных слитка - бронзовый весом около 1 кг и железный весом 0,5 кг.

О характере металлургического производства отчетливое представление дают не только форма и структура древних плавильных печей, но и орудия обработки металла, образцы которых в значительном количестве найдены при раскопках поселений древних рудокопов и металлургов, на древних выработках и в металлургических центрах, а также в других местах. Это тигли, льячки, формы для литья, многочисленные молоты из камня и рога, использовавшиеся для чеканки и холодной ковки металла. Льячки многообразны по форме, часто в виде черпака со сливным носиком и вертикальной ручкой, а также в виде круглой чаши с прямыми стенками.

Наиболее интересную группу орудий обработки металла составляют формы для литья бронзовых орудий и украшений, обнаруженных в ряде поселений древних металлургов Центрального Казахстана. Необычайно оригинальная каменная форма, не имеющая аналогов на всем пространстве Евразии, найдена на стоянке Караганда 19. Она представляет собой подквадратную плитку из диорита, на гладкой поверхности которой фиксируется выразительный контур четырехлопастного углубления для литья бронзовой накладки крестообразной формы, образец которой найден в группе Сангру I.

Каменные формы для литья бронзовых орудий и украшений обнаружены в культурных слоях поселений Жезказгана-Милыкудуке, Соркудуке и Айнаколе. Найдено около 20 матриц, большинство из 
них в обломках. Характерно то, что все литейные формы Жезказгана изготовлены из мягкого девонского песчаника в виде круглых, квадратных и прямоугольных плиток с хорошим бортовым обрамлением и превосходной шлифовкой. На гладких поверхностях этих плиток четко видны негативные изображения различных типов орудий, из которых наибольший интерес представляют матрицы вислообушного топора и плоского кельта. Хорошо сохранились литейные формы из Жезказгана - матрицы для отлива шильев, наконечников копий.

Значительной серией представлены каменные матрицы, использовавшиеся в качестве основы для холодной обработки металла способом вдавления и тиснения, в результате чего создавались элементы гофрировки и рифления, выпуклой и пунсонной орнаментации. Матрицы представляют собой каменные бруски круглого, овального или прямоугольного очертаний, на которых вырезаны круглые ямочки, бороздки различных форм и углубления, представляющие собой негативные изображения различных геометрических узоров. С помощью этих матриц способом вдавливания и тиснения создавались элементы бронзовых украшений. Среди каменных матриц наблюдаются каменные штампы со сквозными отверстиями для холодной штамповки бронзовых блях конусообразной формы, такие бляхи обнаружены на поселениях Каркаралы I, Шортанды-Булак и в др. местах.

В культурном слое поселения Милыкудук найдена матрица в виде прямоугольного бруска с отбитым концом. По гладкой поверхности бруска проходят четыре неглубокие бороздки в виде паралелльных рифлений, соответствующих форме гофрированных узоров на золотых и бронзовых изделиях. Украшения с таким орнаментом - бронзовая обоймочка и булавка, обернутые тонким листом из золота обнаружены в оградах подгруппы Айшрак.

Всего в Сарыарке обнаружены остатки 80 древних плавильных печей, из которых 30 - в Жезказгане, 25 - в Каркаралинской степи, 10 - в бассейне p. Сарысу, 10 - в Улытау. Чаще встречаются круглые печи калбинского типа, обложенные каменными плитами, врытыми на ребро, диаметром до 5 м, высотой 1,2-1,3 м. Bce плавильные печи сопровождаются присутствием шлаков, нередко кремневых и бронзовых орудий, обломков керамики, характерной для эпохи бронзы.

Древние плавильные центры с поселениями сосредоточены вблизи крупных месторождений руд, в огромном горнорудном регионе, к которому относятся Жезказган, долина p. Сарысу, Северное Прибалхашье, Каркаралинские и Баянаульские степи и Северо-Восточный Казахстан. Здесь сохранилось громадное количество древних рудных выработок на медь, олово, золото, свинец и другие металлы. Многочисленные древние выработки, большое число плавильных печей, а также обнаруженные здесь многочисленные предметы из металла свидетельствуют о грандиозных масштабах металлургической индустрии на территории Сарыарки в эпоху бронзы, в ряде случаев сопоставимых с современными. Бурный рост металлургии и домашних промыслов происходит в эпоху средней бронзы (атасуский этап) и поздней бронзы (бегазы-дандыбаевская эпоха) [Маргулан А.Х., 2008а; 2008б]. В этот период техника добычи руды и 
выплавки металла достигли высокого уровня развития, а техника обработки металла приобрела свои многообразные формы, о чем свидетельствуют многочисленные находки. Столь значительный прогресс был связан с тем, что из среды скотоводческих племен выделяются специализированные группы людей, из которых одни совершенствовались в строительном деле при сооружении мегалитических памятников таких, как Бегазы, Аксу-Аюлы, Бугулы III и др., другие - в горном промысле и металлургии, третьи - в художественной обработке металла.

Полиметаллические руды, где медь находится в соединении с оловом, серебром, цинком, свинцом и другими металлами, явились основой получения бронзы и обусловили характер металлургического производства. Результаты спектрального анализа руды и шлаков, их сравнительный анализ отражает сложную палитру естественных примесей разных металлов к меди и дают возможность сделать выводы о том, что плавка руды из полиметаллических месторождений имела комплексный характер, если в руде доминировал один металл (одна основа), то плавка осуществлялась раздельным способом, т.е. конечным продуктом плавки был один металл. Благодаря включению в состав казахстанской бронзы различных металлов, изделия из нее чрезвычайно устойчивы к коррозии. Бронзовые орудия отличаются высоким качеством, прочностью и массивностью. Бронзовые украшения, найденные в большом количестве в могильниках и на древних поселениях, изготовлены из сплава меди с серебром, золотом, цинком, свинцом, висмутом, мышьяком, сурьмой. Их состояние позволяет нам весьма высоко оценить мастерство древних металлургов, искусство литейщиков и мастеров обработки металла. В течение тысячелетий находясь в погребенном состоянии под землей и подвергаясь воздействию воды, предметы из бронзы хорошо сохранились.

Значительным результатом археологических исследований в Центральном Казахстане явилось установление следов появления плавки железа в этом регионе с развитой древней металлургией.

Следующий ряд конкретных данных свидетельствуют о начале плавки железа в Центральном Казахстане в доскифское время. Штуфы железной руды были обнаружены в 1839 г. в культурном слое при раскопках «каменной палаты древних жителей», в 3 км к югу от древних выработок Куу русским горнопромышленником С. Поповым.

Груды хорошо отсортированной железной руды и железный шлак впервые были обнаружены при раскопках поселения Каркаралы III. Культура поселения датируется по керамике началом I тыс. до н.э. и входит в круг памятников бегазыдандыбаевской культуры.

Значительное количество железного шлака, груды хорошо отсортированной и промытой железной руды обнаружены в культурном слое жилищ № 14 и 21 при раскопках поселения древних металлургов Шортанды-Булак. Шлаки и куски промытой железной руды выявлены на дне мастерской возле плавильного очага.

В культурном слое жилища № 21 поселения Шортанды-Булак впервые обнаружены железные наконечники стрел, по форме совершенно сходные с бронзовыми прототипами из групп Айшрак, Ортау, Балакулбол- 
ды и др. Железные шлаки и железные наконечники стрел находились рядом с керамикой эпохи поздней бронзы, характерной для бегазыдандыбаевского времени.

При раскопках жилища № 1 поселения эпохи поздней бронзы Тагибай-Булак (Баянаульский р-н) в культурном слое был обнаружен железный крючок. Крупный обломок железной иглы с петельчатым ушком обнаружен в 1956 г. Г.Н. Щербой на поселении Самембет (Каркаралинский $\mathrm{p}-\mathrm{H})$.

О добыче железной руды и ее плавке в эпоху поздней бронзы свидетельствует ряд древних рудников в Центральном Казахстане, где добывались железные руды: это выработки Восточно-Каркаралинского района Кентобе, Кенказган, Карашокы, Карашошак, Карсы, Жалпак, расположенные в горах Балабуркитты, Бакты и Мыржык. По результатам лабораторных исследований, отсортированная железная руда, найденная на дне мастерской поселения Каркаралы III, по составу совпадает с рудой из древнего рудника Кентобе, расположенного в 50 км на восток от поселения.

Места добычи железа в древности находились в урочище Абиш (рудник Кенказган) в 5 км к северовостоку от Кентобе, рудник Акшокы, расположенный на северной стороне горы Бакты, в 60 км на восток от Каркаралинска.

Места добычи железа в древности находились также в горах Темирши Восточно-Каркаралинского района, Кызыларай в группе Саяк, на западной стороне Каркаралинских гор магнетитовые группы разносов Кызылэспе, Акшагыл, выработки Конуспай, Арзыкул. В Баянаульском районе выработки месторождений железа находятся возле пикета Шакшак, на Мырзашокы, Сарытобе и Ушкан. Значительная группа древних выработок на железо сосредоточена в гоpax Котыр-Кызылтау и Манатау. Это выработки Уста, Темир, Каратемир, Алабуга. Древние выработки железа имеются и в атасуской группе.

Куски железной руды и железные шлаки, железные наконечники стрел обнаружены в комплексе с керамикой, бронзовыми изделиями и орудиями горного дела, характерными исключительно для эпохи поздней бронзы и все вместе состаляющими основу бегазы-дандыбаевской культуры Центрального Казахстана. Находки железного шлака и предметов из железа в памятниках бегазыдандыбаевского времени в корне меняют сложившиеся представления о начале появления железа. Материалы свидетельствуют о том, что начальный этап плавки железа в Центральном Казахстане должен быть отнесен к доскифскому времени (IX-VIII вв. до н.э.).

Выявление огромного количества древних рудных выработок и многочисленных плавильных центров - свидетельство того, что объем производства металла в эпоху бронзы был значительным. Грандиозные отвалы Жезказгана, Кенказгана, Алтынтобе, Саяка, выработок Каркаралы, Баянаула, Караганды и многих других свидетельствуют о том, что из недр Центрального Казахстана было извлечено огромное количество руды и выплавлены значительные объемы металла.

Геологов, исследовавших отвалы древних выработок Центрального Казахстана, постоянно занимал вопрос о количестве извлеченной руды. Он впервые был поднят русским инженером И.П. Шангиным в 
1816 г., когда в течение пяти месяцев им были обследованы древние выработки, раскинутые по степному пространству от Кокчетавского уезда до Северного Прибалхашья. В советское время подсчетом количества извлеченной руды из выработок Центрального Казахстана занимались К.И. Сатпаев, В.А. Пазухин, Г.Н. Щерба и др. Г.Н. Щерба писал: «Размеры выработок указывают на то, что добыча руды в наиболее крупных разработках достигала сотен тысяч тонн, т.е. была значительной даже по современным масштабам» [цит. по: Маргулан, 2001]. По подсчетам Г.Н. Щербы на месторождениях Центрального Казахстана до начала промышленной разработки в XIX в. было добыто около 10 млн. тонн руды, из которой выплавлено 450 тыс. тонн меди. По подсчетам С. Болла, а затем К.И. Сатпаева в Жезказгане в древности было добыто свыше 1 млн. тонн руды, содержавшей не менее 10 тыс. тонн меди.

Перед учеными встает вопрос, для каких целей древними жителями Сарыарки было извлечено столько руды? Объемы извлеченных руд и масштабы металлургического производства, во много раз превышавшие потребность в нем жителей Сарыарки, свидетельствуют о существовании в древности экспорта металла. Металл, прежде всего, шел на удовлетворение хозяйственных и культурных потребностей племен, производство орудий труда, предметов обихода, предметов вооружения, украшений. Памятники эпохи бронзы в Центральном и Северо-Восточном Казахстане содержат большое количество изделий из меди, бронзы, золота, серебра и других цветных металлов, которыми изобилует наша страна. Значительной частью металлургического производ- ства в древности было изготовление предметов вооружения - доспехов, различных типов ножей, кинжалов, боевых топоров, втоков, бронзовых наконечников копий и наконечников стрел, значительное количество которых обнаружено на поселениях Атасу, Аксу-Аюлы, Бегазы, Беласар, Бугулы III, Былкылдак I-III, Мырзашокы, Ортау и др.

Основная масса памятников Сарыарки давно разграблена. Как свидетельствуют архивные документы, кладоискательство в казахских степях, как способ обогащения, достигло апогея в 1830-х гг., к этому времени относятся интенсивные поиски россыпного золота. К поиску подземных сокровищ подключились крупные российские чиновники, офицеры и купцы-горнопромышленники, проводились они под эгидой изыскания золотоносных руд. Кладоискательство, поиски россыпного золота совмещались с добычей и плавкой руд. В этом особенно преуспели купцы Поповы, Сорокины, Мясниковы. Найденные кладоискателями бронзовые предметы и предметы из других металлов расходились по частным коллекциям или шли на переплавку. Большая коллекция бронзовых предметов из Центрального Казахстана хранится в Эрмитаже. И все же даже в разграбленных памятниках эпохи бронзы, особенно атасуского и бегазы-дандыбаевского этапов и в наше время обнаруживается большое число бронзовых предметов в виде орудий труда, оружия, предметов обихода, множества украшений.

В памятниках эпохи ранней бронзы Центрального Казахстана обнаружены первые образцы медных орудий и украшений, в том числе короткие клиновидные ножи, весьма похожие на свои каменные прото- 
типы. В памятниках ранней бронзы Центрального Казахстана находки бронзовых орудий редки. Там господствуют, прежде всего, украшения из меди с геометрическим орнаментом. Большое количество бронзовых орудий и украшений обнаружено в памятниках среднего и особенно позднего периода эпохи бронзы.

Судя по материалам раскопок Жезказгана и поселений Каркаралы, в эпоху ранней и средней бронзы древние рудокопы использовалиеще каменные орудия - отбойники, кайла, клинья, кирки и др. Переход от каменных орудий к металлическим был совершен во второй половине средней бронзы, при переходе от андроновской к бегазы-дандыбаевской культуре. В это время появляются бронзовые массивные орудия: кельты, кирки, кайла, ломы (пешни), вислообушные и плоские топоры, серпы, тесла, молоты и др. Из бронзовых орудий, сделанных в мастерских Центрального Казахстана, наиболее крупными, мощными, явно изготовленными для людей богатырского телосложения, были массивные четырехгранные бронзовые кирки с двумя тупо заостренными рабочими концами длиной до 40-50 см. По сравнению с грубыми каменными кайлами и отбойниками, множество которых найдено в древнейших карьерах Жезказгана, появление в Центральном Казахстане мощного металлического орудия - бронзовой кирки было значительным прогрессом, поскольку это орудие в работе было гораздо производительнее, чем старые каменные кайла. Внушительный внешний вид орудия говорит о том, что применение его позволяло древним рудокопам значительно эффективнее разрушать верхнюю кору месторождений и измельчать рудные жилы.
В музеях Жезказгана, Караганды, Балхаша, Алматы и др. хранятся предметы эпохи бронзы, среди которых орудия труда, предметы вооружения - доспехи, различные типы ножей, кинжалов, боевых топоров, втоков, бронзовых наконечников копий и наконечников стрел, предметы домашнего обихода, украшения.

\section{Заключение}

Зарождение и развитие горного дела и металлургии в Сарыарке с древнейших времен было обусловлено уникальными месторождениями полиметаллических руд, сосредоточенными в Жезказгане, Северном Прибалхашье, Каркаралинской, Баянаульской и Карагандинской степях. Благодаря этим сокровищам, во II тыс. до н.э. Центральный Казахстан на Евразийском континенте стал центром металлургии, когда медь и золото получали не только для потребностей местного населения, но также для широкого межплеменного обмена и экспорта. Свидетельством этого являются многочисленные древние выработки, следы металлургического производства в древних поселениях Милыкудук, Айнаколь, Соркудук, Атасу, Улытау, Каркаралы, Шортанды-Булак и многих других, сохранившихся до наших дней. В культурных слоях поселений обнаружены поды сыродутных печей, горные орудия, шлаки, литейные формы, груды отсортированных руд, места обогащения и флотации, дошедшие до нас в виде остатков древних искусственных водоемов, плотин, запруд. При раскопках поселений и гробниц выявлено множество предметов из бронзы - орудий труда, предметов вооружения и бытового обихода, украшений.

На территории Центрального, Северо-Восточного и Восточного 
Казахстана сохранилось множество древних выработок, отвалов, карьеров, забоев, шахт, штолен. Среди них выделяются рудные объекты - комплексы Жезказган, Каражал, группы рудников Северного Прибалхашья, Каркаралинской, Баянаульской, Карагандинской степей, Северной Бетпакдалы.

Культура эпохи бронзы в Сарыарке развивалась постепенно, на протяжении многих сотен лет. Ее истоки прослеживаются в позднем неолите. Эта культура достигает своего расцвета к концу II и в начале I тыс. до н.э. (XI-XII вв. до н.э.). Расцвет металлургии бронзы в эту эпоху был подготовлен всем предшествующим развитием.

Наши далекие пращуры прошли долгий путь в несколько тысячелетий накопления опыта добычи и плавки руды, прежде чем пришли к расцвету в эпоху поздней бронзы. В V-IV тыс. появились первые признаки интереса к самородной меди. При раскопках неолитических стоянок в Жезказгане и Караганде обнаружены куски различных минералов - малахита, азурита, халькопирита, самородной меди. Эти минералы составляют основу руд, добываемых в Жезказгане и в наше время. Домашние очаги неолитических племен Жезказгана были сложены из медистого песчаника, содержащего значительный процент окисленной медной руды. Перед глазами неолитического человека ежедневно разворачивался удивительный процесс, когда при сильном костровом огне плиты из руды плавились и образовывали прозрачные натеки. Этот эмпирический опыт имел решающее значение для истории человечества, человеческой цивилизации, он открывал перспективу ее безграничного развития. На протяжении нескольких тысячелетий человек накапливал опыт плавки медной руды сначала на костре, затем в небольших ямах, обмазанных глиной (Милыкудук). Следы плавки руды на костре в местах ее добычи установлены на р. Жезды, на месторождении Алтыншокы, на вершинах гор Жангызтау и Кызыларай, на югозападных склонах Саякского массива. На дне домашних очагов террасовых неолитических стоянок Жезказгана (Петрохолм, Кресто 21, 33) сохранились скопления золы, смешанной с мелкими медными шариками, а также сильно прокаленные камни с прозрачными натеками.

На раннем этапе объем добычи и плавки медной руды был незначительный, отвалы древнейших выработок малозаметны, сильно задернованы, следы сортировки руды, ее дробления, обогащения и промывки отсутствуют. Здесь встречаются обломки керамики, характерные для ранней бронзы. По хронологической шкале эти выработки можно отнести к периоду, охватывающему половину III и начало II тыс. до н.э.

Более интенсивный характер добычи руды и плавки металла отмечается в начале II тыс. до н.э. (конец ранней и начало средней бронзы). С этого времени на территории Сарыарки отмечается заметный прогресс в древнем горном деле, связанный с внедрением идеи дробления и мокрого обогащения медной руды. Эти новшества делают руду легкоплавкой, доступной для восстановительной циркуляции. Для измельчения руды сначала использовались каменные, позднее бронзовые рудодробильные орудия. Такие орудия часто встречаются в местах древних рудоразработок, в «сплесках», на поселениях древних горняков и металлургов. 
Начиная со второй половины средней бронзы (XIV-XIII вв. до н.э.) племена, обитавшие в Сарыарке, стали осваивать полиметаллические месторождения, что явилось новым мощным импульсом в развитии металлургии.

Карьеры и отвалы выработок эпохи поздней бронзы (X-VIII вв. до н.э.) отличаются многочисленностью и грандиозностью, что свидетельствует о большой интенсивности работ по добыче и плавке руды в это время, о невиданном масштабе работ. К классическим памятникам горного дела и металлургии этого времени относятся уникальные рудные выработки Кресто-Воздвиженский, Златоуст, Раймунд в Жезказгане, громадные массивы выработок и металлургические центры Саяк, Коунрад, Кенказган, Тесиктас, Шурук, Шакпактас, Аулие, Имантау и др.

Представленные факты в целом свидетельствуют о совершенно самостоятельном возникновении и развитии металлургии в Сарыарке, что было обусловлено многочисленными медными, оловянными, свинцовосеребряными и полиметаллическими месторождениями. В эту историческую эпоху вместе с горным делом и металлургией отмечается громадный скачок в строительном деле и архитектуре, о чем свидетельствуют оседлые поселения с жилищами, имевшими толстые стены, памятники монументальной каменной архитектуры Бегазы, Бугулы, Сангру и др. Предметы, обнаруженные в памятниках, свидетельствуют о достигнутых высотах совершенства в домашних ремеслах, керамическом искусстве, в искусстве обработки металла, кости и камня.

Несомненно, Сарыарка, как центр древней цивилизации, имела решающее значение для развития соседних регионов. В эпоху бронзы устанавливаются торговые и культурные связи между западными и восточными регионами Евразии. При этом ведущая роль в торговом обмене принадлежала казахстанскому металлу - меди, олову, бронзе, золоту.

Добычей и плавкой руд занимались большие группы людей, владевшие специальными знаниями и навыками в горном деле и металлургии. Иначе как можно объяснить огромный масштаб работ, проделанных в древности, многочисленные выработки, отвалы, «сплески», места обогащения и плавки руд? Распространение рудных выработок на огромной территории Сарыарки вплоть до самого центра пустыни Бетпакдала было обусловлено культурно-экономическим подъемом племенной организации. Этому способствовали горный промысел и металлургия, достигшие масштабных форм производства и ставшие ведущими отраслями хозяйства.

На высшем этапе развития бронзовой культуры на территории Сарыарки (X-VIII вв. до н.э.) наблюдается специализация труда и в других сферах деятельности человека - строительном деле, керамическом и ювелирном искусстве. Бурные социально-экономические процессы, охватившие данную эпоху связаны с ростом численности населения и ростом поголовья скота, что делает невозможным обитание человека в одном месте, в условиях обжитой родовой территории и устаревшего пастушеского скотоводства. Возникает необходимость в освоении новых территорий, расширении пастбищных угодий, передвижении племен с юга и юго-запад на север через пустыню Бетпакдала, что, в 
свою очередь, стимулирует освоение месторождений и добычу руды в Бетпакдале. Вследствие этих процессов древние выработки широкой полосой идут по всему Центральному и Северо-Восточному Казахстану, тянутся по степям от Кокчетавских гор до пустыни Бетпакдала, от Майкаина до Северного Прибалхашья.

Открытие металла явилось революционным событием в истории человечества. Для зарождения и развития в Сарыарке горного дела и металлургии в древности были уникальные богатства недр, отсутствующие в иных местах земного шара. Это месторождения медных, оловянных и полиметаллических руд, сконцентрированные в южных широтах Центрального Казахстана и в северовосточной части Сарыарки. Основные узлы древних выработок на медь были сосредоточены в Жезказгане, в Каркаралинской и Баянаульской степях, в Северном Прибалхашье, где добывались медь, олово и другие металлы. Это те места, где появился первый металл (медь), где впервые сформировалась древнейшая бронзовая культура.

В статье «Семь граней Великой степи» Первый Президент РК Н.А. Назарбаев поднимает вопрос о появлении на нашей земле до новой эры технологических новаций, что позволяет позитивно рассматривать нашу национальную историю [Назарбаев, 2018]. Задолго до указанной статьи была написана и издана монография «Сарыарка. Горное дело и металлургия в эпоху бронзы», где А.Х. Маргулан на основе фактического материала приходит к выводу, что горное дело и металлургия наряду со скотоводством и земледелием были древнейшими видами хозяйственной деятельности протоказахских пле- мен. В результате крупных объемов выплавленной меди в те далекие времена появилась меновая стоимость и экспорт меди. О масштабах этой формы деятельности говорит факт экспорта меди по караванным путям в древний Рим, Китай и другие страны.

Возвращаясь к теме статьи, необходимо остановиться на работе ученого «Древние казахские племена и образование Казахского ханства», где А.Х. Маргулан пишет о том, что на протяжении длительного исторического времени существовала тенденция к сближению древних протоказахских племен, что привело к образованию единого этноса. Образование в раннем средневековье Западно-Тюркского каганата было первым опытом и важнейшим этапом в истории объединения протоказахских племен, в значительной степени подготовившего последующую консолидацию племен и образование Казахского ханства. После распада каганата на основе древней военной тактики деления войск на мын (тысяча) и жуз (сто) формируется объединение «Үшжүз», в домонгольское время в результате усиления тенденции сближения племен появляется союз племен «алаш». Важнейшим этапом в процессе консолидации протоказахских племен было образование «Казахского ханства». В работе А.Х. Маргулана «Древние казахские племена и образование Казахского ханства» - первого государства в истории казахов описан памятник, имеющий для казахского народа огромное историческое значение. Как пишет ученый, во времена образования Казахского ханства на берегу p. Сарысу в Центральном Казахстане состоялся синклит, в котором приняли участие вожди крупных племен 
трех жузов, и на скале Тамгалы-тас была высечена надпись на кыпчакском языке об объединении племен в единый казахский народ. Это место официального провозглашения казахского народа. В народе его называют «қазақтың ұран шақырып, қазақ біріккен жері». Одним из первых, кто открыл этот памятник, был К.И. Сатпаев. Его интересовала история этого памятника, и он посоветовал А.Х. Маргулану заняться ею. Результатом этого явилась монография «Древние казахские племена и образование Казахского ханства» [Mаргулан, 2012]. Условием объединения племен в один народ и образование Казахского ханства явились общий язык и территория, кочевое скотоводство, составлявшее экономическую основу казахских племен, один уклад жизни, близкие обычаи и традиции, психофизические характеристики и соответствующий им стереотип поведения обитателей Великой степи.

Общеизвестно, что в годы подготовки к юбилею Ч.Ч. Валиханова К.И. Сатпаев, знавший о том, что А.Х. Маргулан еще в студенческие и последующие годы занимался сбором материалов о Ч.Ч. Валиханове в ленинградских, московских и других архивах СССР, поручил Алькей Хакановичу возглавить группу ученых по подготовке к изданию трудов Ч.Ч. Валиханова. Группой чокановедов во главе с А.Х. Маргуланом были изданы «Избранные произведения» Ч.Ч. Валиханова в 1958 г. [Валиханов, 1958] и «Собрание сочинений» великого казахского ученого в пяти томах [Валиханов, 1961; 1962; 1964; $1968 ; 1972]$.

Таковы в общих чертах результаты сотрудничества К.И. Сатпаева и А.Х. Маргулана.

\section{ЛИТЕРАТУРА} $1958.641 \mathrm{c}$.

1. Валиханов Ч.Ч. Избранные произведения. Алма-Ата: Изд-во АН КазССР,

2. Валиханов Ч.Ч. Собрание сочинений в 5-ти томах. Т. 1. Алма-Ата: Изд-во АН КазССР, 1961. 777 с.

3. Валиханов Ч.Ч. Собрание сочинений в 5-ти томах. Т. 2. Алма-Ата: Изд-во АН КазССР, 1962. 796 с.

4. Валиханов Ч.Ч. Собрание сочинений в 5-ти томах. Т. 3. Алма-Ата: Изд-во АН КазССР, 1964. 623 c.

5. Валиханов Ч.Ч. Собрание сочинений в 5-ти томах. Т. 4. Алма-Ата: Изд-во АН КазССР, 1968. 782 с.

6. Валиханов Ч.Ч. Собрание сочинений в 5-ти томах. Т. 5. Алма-Ата: Изд-во АН КазССР, 1972. 142 c.

7. Маргулан A.X. Собрание сочинений в 14-ти томах. Т. 2. Сарыарка. Горное дело и металлургия в эпоху бронзы. Джезказган - древний и средневековый металлургический центр (городище Милыкудук) / Сост. Д.А. Маргулан, Д. Маргулан. Алматы: ДайкПресс, 2001. 144 с. + вкл. 40 с. 2008 a.

8. Маргулан A.X. Собрание сочинений в 14-ти томах. Т. 5. Алматы: «Алатау»,

9. Маргулан А.Х. Собрание сочинений в 14-ти томах. Т. 6. Алматы: «Алатау», 20086. 494 c.

10. Маргулан А.Х. Собрание сочинений в 14-ти томах. Т. 13. Алматы, 2012. 
11. Назарбаев Н.А. Семь граней Великой степи. URL: http://www.akorda.kz/ru/ events/statya-glavy-gosudarstva-sem-granei-velikoi-stepi (дата обращения: 09.07.2019 г.).

12. Сатпаев К.И. Избранные труды в 5-ти томах. Т. 1. Джезказганский меднорудный район. Алма-Ата: Наука, 1967. 280 с.

13. Сатпаев К.И. Избранные труды в 5-ти томах. Т. 2. Полезные ископаемые Джезказган-Улутауского района. Алма-Ата: АН КазССР, 1968. 222 с.

14. Сатпаев К.И. Избранные труды в 5-ти томах. Т. 5. Статьи, публицистика и материалы к биобиблиографии. Алма-Ата: АН КазССР, 1970. 326 с.

\section{Сведения об авторе:}

Маргулан Данель Алькеевна - спецредактор 14-титомного «Собрания сочинений А.Х. Маргулана» (г. Алматы, Казахстан); dmargulan@list.ru

\section{Қ.И. СӘТПАЕВ ЖӘНЕ Ә.Х. МАРҒҰЛАН - ЫНТЫМАҚТАСТЫҚ ТАРИХЫ}

\section{Д.Ә. Марғұлан}

Биылғы жыл Қ.И. Сәтпаевқа 120 жыл және Ә.Х. Марғұланға 115 жыл толды. Қ.И. Сәтпаев пен Ә.Х. Марғұлан Павлодар облысының Баянауыл өлкесінде дүниеге келген. Екеуі де 1920-шы жылдары Семейдің педагогикалық техникумында оқыған. Кейіннен Қ.И. Сәтпаев оқуын Сібір технологиялық институтында (Том қ.), ал Ә.Х. Марғұлан Ленинград мемлекеттік университетінің шығыстану факультетінде жалғастырады. Том институтын бітіргеннен кейін Қаныш Имантайұлы Қарсақпайға жұмысқа жіберіледі де, онда 1928 жылдан 1941 жыл аралығында, яғни Алматыда КСРО Ғылым академиясының Қазақ филиалы ашылғанға дейін жұмыс істейді. Ә.Х. Марғұлан КСРО Ғылым академиясының шешімімен 1938 жылы Материалдық мәдениет тарихы институтынан (Ленинград) КСРО Ғылым академиясының Қазақ филиалының тарих секторына, содан соң 1946 ж. археология секторына жіберіледі. Осы кезден бастап ұзақ жылдар бойы Ә.Х. Марғұлан үздіксіз жетекшілік жасаған Орталық Қазақстан археологиялық экспедициясының тарихы басталады.

Түйін сөздер: археология, Қ.И. Сәтпаев, Ә.Х. Марғұлан, КСРО Ғылым академиясының Қазақ филиалы, ынтымақтастық

\section{K.I. SATPAYEV AND A.Kh. MARGULAN - COOPERATION HISTORY}

\section{D.A. Margulan}

This year is the 120th birthday of K.I. Satpayev and 115th of A.Kh. Margulan. K.I. Satpayev and A.Kh. Margulan were born in Bayanaul. They studied in the 1920th in Semipalatinsk pedagogical technical school. Afterwards K.I. Satpayev continued training at the Siberian Institute of Technology (Tomsk), and A.Kh. Margulan - at the Leningrad State University at the faculty of oriental studies. After graduation of Tomsk institute Kanysh I. was directed to work to Karsakpay where he worked from 1928 to 1941 - before formation of Kazakh branch of the Academy of Sciences of the USSR in Alma-Ata. In 1938 by the decision of the Presidium of the Academy of Sciences of the USSR A.Kh. Margulan was sent from the Institute of history of material culture (Leningrad) to the sector of history of Kazakh branch of the Academy of Sciences of the USSR, then in 1946 - to the sector of archaeology. From this point begins the history of Central Kazakhstan archaeological expedition, whose permanent head for many years was A.Kh. Margulan.

Keywords: archaeology, K.I. Satpayev, A.Kh. Margulan, Kazakh branch of the Academy of Sciences of the USSR, cooperation.

\section{REFERENCES}

1. Valikhanov, Ch. Ch. 1958. Izbrannye proizvedeniya (Selected Works). Alma-Ata: Academy of Sciences of the Kazakh SSR Publ. (in Russian).

2. Valikhanov, Ch. Ch. 1961. Sobranie sochinenii v 5-ti tomah (Collected Works in 5 volumes), 1. Alma-Ata: Academy of Sciences of the Kazakh SSR Publ. (in Russian). 
3. Valikhanov, Ch. Ch. 1962. Sobranie sochinenii v 5-ti tomah (Collected Works in 5 volumes), 2. Alma-Ata: Academy of Sciences of the Kazakh SSR Publ. (in Russian).

4. Valikhanov, Ch. Ch. 1964. Sobranie sochinenii v 5-ti tomah (Collected Works in 5 volumes), 3. Alma-Ata: Academy of Sciences of the Kazakh SSR Publ. (in Russian).

5. Valikhanov, Ch. Ch. 1968. Sobranie sochinenii v 5-ti tomah (Collected Works in 5 volumes), 4. Alma-Ata: Academy of Sciences of the Kazakh SSR Publ. (in Russian).

6. Valikhanov, Ch. Ch. 1972. Sobranie sochinenii v 5-ti tomah (Collected Works in 5 volumes), 5. Alma-Ata: Academy of Sciences of the Kazakh SSR Publ. (in Russian).

7. Margulan, A. Kh. 2001. Sobranie sochinenii v 14-ti tomah (Collected Works in 14 volumes), 2. Almaty: "Dayk-Press" Publ. (in Russian).

8. Margulan, A. Kh. 2008a. Sobranie sochinenii v 14-ti tomah (Collected Works in 14 volumes), 5. Almaty: “Alatau” Publ. (in Russian).

9. Margulan, A. Kh. 2008b. Sobranie sochinenii v 14-ti tomah (Collected Works in 14 volumes), 6. Almaty: “Alatau” Publ. (in Russian).

10. Margulan, A. Kh. 2012. Sobranie sochinenii v 14-ti tomah (Collected Works in 14 volumes), 13. Almaty (in Russian).

11. Nazarbayev, N.A.URL:http://www.akorda.kz/ru/events/statya-glavy-gosudarstvasem-granei-velikoi-stepi (09.07.2019).

12. Satpayev, K. I. 1967. Izbrannye trudy v 5-ti tomah (Selected Works in 5 volumes), 1. Alma-Ata: Academy of Sciences of the Kazakh SSR Publ. (in Russian).

13. Satpayev, K. I. 1968. Izbrannye trudy v 5-ti tomah (Selected Works in 5 volumes), 2. Alma-Ata: Academy of Sciences of the Kazakh SSR Publ. (in Russian).

14. Satpayev, K. I. 1970. Izbrannye trudy v 5-ti tomah (Selected Works in 5 volumes), 5. Alma-Ata: Academy of Sciences of the Kazakh SSR Publ. (in Russian).

\section{About the Author:}

Margulan Danel A. Special Editor of the "Collected Works of A.Kh. Margulan" in 14 volumes, Almaty, Kazakhstan; dmargulan@list.ru

\footnotetext{
Мүдделер қақтығысы туралы ақпаратты ашу. Автор мүдделер қақтығысының жоқтығын мәлімдейді. / Раскрытие информации о конфликте интересов. Автор заявляет об отсутствии конфликта интересов. / Disclosure of conflict of interest information. The author claim no conflict of interest.

Мақала туралы ақпарат / Информация о статье / Information about the article.

Редакцияға түсті / Поступила в редакцию / Entered the editorial office: 19.06.2019.

Рецензенттер мақұлдаған / Одобрено рецензентами / Approved by reviewers: 26.06.2019.

Жариялауға қабылданды / Принята к публикации / Accepted for publication: 03.07.2019.
} 